\title{
Relationship Of Husband's Support With Mother Interests To Use Contraceptive Implant In The Work Area Health South Alalak Banjarmasin
}

\author{
Rima Minarni ${ }^{*}$ \\ ${ }^{1}$ STIKES Sari Mulia Banjarmasin \\ rimaminarni23@yahoo.com \\ Hairiadi Widodo ${ }^{1}$ \\ ${ }^{1}$ STIKES Sari Mulia Banjarmasin \\ Hariadi_widodo@stikessarimulia.ac.id \\ Sarkiah $^{2}$ \\ ${ }^{2}$ AKBID Sari Mulia Banjarmasin \\ sarkiah@akbidsarimulia.ac.id
}

\begin{abstract}
Objective: To analyze the relationship of husband's support to the mother's interest (wife) in using implant contraception in the working area of Alalak Selatan health center.

Method: This research use cross sectional design with quantitative approach. The population in this study were all implanted contraceptive acceptor in Alalak Selatan Public Health Working Area in January and February of 2017, which amounted to 48 people, with the type of sampling using random sampling and data collection using questionnaire.

Result: The result of bivariate analysis using gamma test because it has ordinal category, and obtained $p$ - value $=0,003$ because $p>0,05(0,003<0,05)$ so that there is a significant relationship between husband support with mother interest (wife) in using implant contraception in the Alalak Selatan Public Health Working Area.

Conclusion: Based on the results of research, it can be concluded that all variables studied have a significant relationship.
\end{abstract}

Keywords: Contraceptive Implant, Husband Support, Mother's Interest,

\section{INTRODUCTION}

In the use of contraceptives, there are several factors that influence the selection, and one of them is an external factor in the form of husband support [1]. The role and responsibility of men in reproductive health, especially in Family Planning (KB), is very influential on health [2]. According to Hartanto (2008) [3], contraception cannot be used wife without the cooperation of husband and wife and mutual trust.
Interest is something that happens from the attention that is not only lasting once from objects that are considered attractive or valuable to him. In other words, the tendency to investigate and manipulate by someone long will cause interest.

Based on data from health office of Banjarmasin city, it is found that Alalak Selatan health center is the highest health centers in implant $\mathrm{kb}$ users from 26 health centers in Banjarmasin area 2015. Based on a 
preliminary study which conducted by researchers at Alalak Selatan Public Health Center on 07 March 2017, obtained in 2016 there were 172 people taking contraceptive implants, and in January and February, there were 48 people taking implants. Researchers asked 6 implant users about their husband's support and maternal interest in using implant contraception in the Alalak Selatan Public Health Center area. There are 3 people who are interested and get support from husband; 1 person answered follow-up friends but not supported by the husband but still using implant contraception, and 2 people answered their own wishes and husbands never interfered in the selection of contraceptives so far.

Based on the description above, the researchers are interested in conducting research with the title Relationship Husband Support On Mother's Interest In Using Contraception Implant?

\section{METHODS}

The data taken in this research are all acceptors of implant contraception in the work area of Alalak Selatan Public Health Center.

This research was conducted in June 2017. Sampling in this study was done by random sampling in the number of samples which amounted to 32 respondents.

The data were used by looking at the number of $\mathrm{Kb}$ implant users from Dinkes Banjarmasin and Alalak Selatan Health
Center and supported by the results of husband support questionnaires and interests of mothers. The instrument used is a combination of secondary and primary data in the number of implant users in the Puskesmas Alalak Selatan and supported the results of the husband support questionnaire and the interests of mothers who were directly filled by the mother in the work area of Alalak Selatan Public Health Center which then processed through computer with data analysis program, that is Gamma.

\section{RESULTS}

The univariate analysis of husband support in the work area of Alalak Selatan public health center is as follows:

Table 1. Frequency Distribution of The Husbands' Support in Using Implant Contraception in the Work Area of Alalak Selatan Public Health Center in Banjarmasin

\begin{tabular}{cccc}
\hline No & $\begin{array}{c}\text { Husbands' } \\
\text { support }\end{array}$ & Frequency & Percentage (\%) \\
\hline $\mathbf{1}$ & High & 3 & 9.4 \\
\hline $\mathbf{2}$ & Moderate & 17 & 53.1 \\
\hline $\mathbf{3}$ & Low & 12 & 37.5 \\
\hline & Total & 32 & 100 \\
\hline
\end{tabular}

Source: Primary Data

Based on table 1, it can be seen that from 32 respondents, there are respondents in the category of high support of husband as much as 3 people (9.4\%), support husband is 17 people (53.1\%) and husband support low as many as 12 people $(37.5 \%)$.

Table 2. Distribution of Frequency of Mothers' Interest Using Implant Contraception In Working Area of Alalak Selatan Public Health Center Banjarmasin

No Interest Frequency $\quad$\begin{tabular}{c} 
Percentage \\
\hline
\end{tabular}




\begin{tabular}{cccc}
\hline $\mathbf{1}$ & High & 2 & 6.3 \\
\hline $\mathbf{2}$ & Moderate & 19 & 59.3 \\
\hline $\mathbf{3}$ & Low & 11 & 34.4 \\
\hline & Total & 32 & 100 \\
\hline
\end{tabular}

Source: Primary Data

Based on table 2, it can be seen that from 32 respondents, respondents in the highinterest category as much as 2 people $(6.3 \%)$, the moderate interest of 19 people $(59.3 \%)$ and low interest of 11 people $(34.4 \%)$.

The results of bivariate analysis of the relationship of husband's support with interest in using mother's implant contraception in the work area of Alalak Selatan Banjarmasin.

Tabel 3. Correlation of Husbands' and Mothers' Interest in Using Implant Contraception in the Work Area of Alalak Selatan Public Health Center in Banjarmasin

\begin{tabular}{|c|c|c|c|c|c|c|c|c|c|}
\hline \multirow[t]{2}{*}{$\begin{array}{c}\text { Husba } \\
\text { nds' } \\
\text { suppor } \\
\text { t }\end{array}$} & & & & $\begin{array}{c}\text { Mot } \\
\text { hers } \\
, \\
\text { inter } \\
\text { est }\end{array}$ & & & \multirow[t]{2}{*}{$\sum$} & \multirow[t]{2}{*}{$(\%)$} & \multirow[t]{2}{*}{$\mathrm{p}$} \\
\hline & $\mathrm{T}$ & $\%$ & $\mathrm{~S}$ & $\%$ & $\mathrm{R}$ & $\%$ & & & \\
\hline High & 2 & $\begin{array}{c}66 \\
.7\end{array}$ & 1 & 33.3 & 0 & 0 & 3 & 100 & \\
\hline $\begin{array}{l}\text { Moder } \\
\text { ate }\end{array}$ & 0 & 0 & 13 & 76.5 & 4 & 23.5 & 17 & 100 & $\begin{array}{c}0.00 \\
3\end{array}$ \\
\hline Low & 0 & 0 & 5 & 41.7 & 7 & 58.3 & 12 & 100 & \\
\hline Total & 2 & $\begin{array}{l}6 . \\
3\end{array}$ & 19 & 59.3 & 11 & 34.4 & 32 & 100 & \\
\hline
\end{tabular}

Source: Primary Data

Based on table 3, there are 13 respondents with the interests of the mother who support her husband is also medium and 4 respondents with low interest that support her husband. From the result of bivariate analysis using gamma test because it has ordinal category, obtained $\mathrm{p}$-value $=0,003$ because $\mathrm{p}<0,05(0,003<0,05)$ hence can be stated there is a significant relation between husband support with mother interest in using implant contraception in the Working Area of Puskesmas Alalak Selatan.

\section{DISCUSSION}

1. The Husbands' Support

The frequency of support of husbands with high support category of husbands amounted to 3 people $(9.4 \%)$, husband support amounted to 17 people (53.1\%) and husband support is low there are 12 people $(37,5 \%)$.

The researchers assume that high husbands support can be due to the high awareness and concern of husbands against contraception that is being used by mothers so that husbands can provide good support, such as emotional support. Husband is also always accompanying the mother when choosing contraception, seen from the answer of the mother in the questionnaire where the husband always provides motivation for the mother about contraception that followed. Mothers and husbands are also deliberate in the contraceptive selection, and husbands always listen to maternal complaints and encourage mothers so that mothers feel more confident with the contraceptives they use.

This is in accordance with the opinions in KBBI, (2007) [4]. Support is something that is encouraged, encouraged or to encourage someone, that the husband is the man who is the official spouse of a married woman (wife).

This is also in accordance with Chaniago's theory, which states that the husband is a wife's spouse (the father of the children). 
Husband has a full responsibility in a family and husband has an important role, where the husband is demanded not only as a breadwinner but the husband as a motivator in various policies that will be decided including family planning [5].

\section{The Mothers' Interest}

Based on the results in Table 4.4, there were 2 people $(6.3 \%)$, moderate interest (19\%) (59.3\%) and $11(34.4 \%)$ low interest.

According to the researcher's assumptions, the mother's interest is mother's interest in contraception, so there is more curiosity about the contraception, one of them is implant contraception. It makes mothers want to know more about implant contraception. This is also due to the free MKJP contraception program from the government at Alalak Selatan Community Health Center which causes mothers to use long-term contraception, especially implant contraception. Of 32 respondents who previously used injectable contraception, there were 21 people and using pill contraceptives 11 people.

According to the researcher's assumptions, the support of husbands with an interest in using contraceptive implants is interconnected because husbands support is one that makes mothers feel confident in using implant contraception. Without his support from the husband then the interest of the mother will also be reduced. The role of the husband in the form of support is the most meaningful thing for the mother. Mother also felt not alone who is responsible for choosing contraceptives but her husband also played a role in that.

The results of this study are in line with Ramadhita Isnaeni (2015) research, an interest that arises in the heart of a wife can be caused by the encouragement and support from outside such as from the husband or family. Husband's support is usually a form of concern and gives a sense of comfort and confidence in making such decisions in the selection of contraceptives [6]. Lack of husbands support will affect the wife's interest and confidence to choose the contraception to be used with the results of research. Of the 42 respondents who have less husband support and have low interest in the use of family planning after birth as many as 25 respondents $(59.5 \%)$, a good husband and have high interest amounted to 2 respondents (4.8\%). Correlational analysis test results, obtained Kendall Tau value of $\rho=0,000$ ( $\rho=$ $<0.05)$. The results of this study are also in line with the opinion of the pendit (2007) In the use of contraceptives, there are several factors that influence in the selection of one of the external factors in the form of husband support [1].

\section{REFERENCES}

[1]. Pendit, B.U 2007. Ragam Metode Kontrasepsi. Jakarta: EGC. 
[2]. BKKBN. 2007. Laporan Pencapaian Presentase KB Indonesia Tahun 2007. Jakarta : BKKBN Jakarta.

[3]. Hartanto, 2008. Keluarga Berencana dan Iskandar., Harun 2010. Tumbuhkan Minat Kembangkan Bakat. St Book.

[4]. Kamus Besar Bahasa Indonesia. 2002. Edisi Ketiga. Jakarta : Balai Pustaka Kontrasepsi. Jakarta: Pustaka Sinar Harapan.

[5]. Firdawsy Nuzula. 2015. Faktor-Faktor Yang Berhubungan Dengan Pemakaian Implant Pada WUS [internet]. [diunduh 2015]. Tersedia pada: Http//pps.unud.ac.id

[6]. Ramadhita Isnaenani. 2015. Hubungan Dukungan Suami Dengan Minat Ibu Hamil Dalam Pemakaian $\mathrm{Kb}$ Pasca Persalinan [internet]. [diunduh 2015]. Tersedia pada: Http//opac.unisayoyga.ac.id 